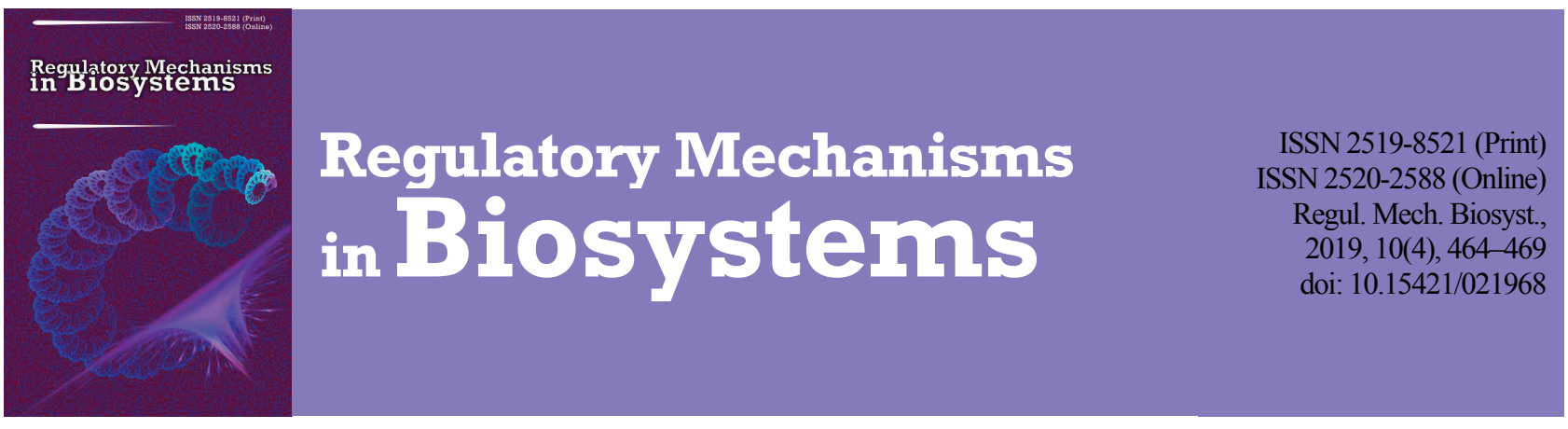

\title{
Population dynamics and types of habitats at breeding sites of raptors (Falconiformes) of the Donetsk Ridge along a gradient of anthropogenic disturbance
}

\author{
M. O. Vysochyn \\ National Nature Park “Dvorichanskyi”, Kharkiv Region, Ukraine
}

Article info

Received 10.10.2019

Received in revised form

04.11.2019

Accepted 06.11.2019

National Nature Park "Dvorichanskyi",

Slobozhanska st, 5, Dvorich-

na, 62701,

Kharkiv Region, Ukraine.

Tel: +38-050-626-24-41.

E-mail:dvorichnpp@ukr.net

\begin{abstract}
Vysochyn, M. O. (2019). Population dynamics and types of habitats at breeding sites of raptors (Falconiformes) of the Donetsk Ridge along a gradient of anthropogenic disturbance. Regulatory Mechanisms in Biosystems, 10(4), 464-469. doi:10.15421/021968
\end{abstract}

Studies of diurnal birds of prey may be quite indicative of the state of natural ecosystems and of the level of impact of humaninduced factors on their functions. The aim of this work was to analyse the long-term dynamics of the raptor populations within the Donetsk Ridge, to identify which habitat or habitat mosaics are preferred in nesting territories and home ranges depending on the level of anthropogenic transformation of the environment. The studies were conducted in 1999-2019. The total length of the walking routes was $2,864 \mathrm{~km}$ while a distance of $1,548 \mathrm{~km}$ was covered by car routes. 306 nests of the birds of prey or those potentially belonging to the members of this group were found and re-examined. The long-term dynamics of the population of Falconiformes was characterized by a general decline in the numbers of most species. There was a loss of representatives of the boreal and desert-steppe faunistic complexes and simultaneous increase in the participation of representatives of the nemoral and forest steppe faunistic complexes associated with the floodplain forests of the Siversky Donets River valley and the bayrak oak forests of the central part of the Donetsk Ridge. The impact of the anthropogenic factor on the dynamics of the population of the birds of prey is ambiguous. For the species which are sensitive to changes in the environment, such as the European Honey Buzzard, the Northern Goshawk, the Merlin and the Red-footed Falcon, a general negative dynamics of the populations is observed. The positive trend in the numbers of the Long-legged Buzzard and the Saker Falcon is linked to the expansion of the both species into the territory of the Donetsk Ridge. The habitat structure of the nesting territories is quite diverse in different species of diurnal birds of prey. This is especially noticeable in the ratio of forest and grassland habitats. Based on the selectivity index, we found that the vast majority of the raptors of the Donetsk Ridge prefer temperate broad-leaved forests when choosing nesting territories. The structure of the home ranges of all forest species of diurnal birds of prey not only depends on the optimal ratio of open and forested areas but on the presence of ecotones of considerable length which originated in the complex mosaics of habitat complexes. The stable number of dendrophiles and the disappearance (decrease in number) of sclerophiles and campophiles indicates the least anthropogenic transformation of forest habitats and a radical transformation of open spaces - meadows and steppes. The most successful were eurytopic birds of prey and species with pronounced anthropotolerance.

Keywords: birds of prey; forest steppe; nesting territories; home ranges; grassland; anthropotolerance.

\section{Introduction}

In recent centuries the ecosystems of the steppe zone and forest steppe zone of Ukraine have undergone dramatic changes caused by the agricultural transformation of virgin steppe areas, deforestation and the creation of artificial forests, industrial development, ups and downs in the intensity of agriculture, an increase in the area of human settlements and so on (Banik \& Korshunov, 2014; Kul'bachko et al., 2015; Brygadyrenko, 2015, 2016). All these changes have been quite prominent within the Donetsk Ridge, Eastern Ukraine. The raptors (Falconiformes), due to their ecological traits (high life expectancy, status of higher-order consumers, distinct habitat requirements for breeding and feeding sites), may be a key group for detecting ecosystem changes and making indirect assessments of biological diversity (Butet et al., 2010; Milobog, 2012; Burgas et al., 2014).

The aim of this work was to analyse the long-term dynamics of the raptor populations within the Donetsk Ridge, to identify which habitat or habitat mosaics are preferred in nesting territories and home ranges (Galushin, 1971; Newton, 1979) depending on the level of anthropogenic transformation of the environment.
Similar work was carried out in Western Europe e.g. estimation of the dependence of breeding success in the Common Buzzard (Buteo buteo) and the Northern Goshawk (Accipiter gentilis) on their choice of habitats (Kruger, 2002), the impact of urban density, road networks and forest cover on the distribution of raptors (Palomino \& Carrascal, 2007), study of the tolerance of the Common Buzzard to human disturbance (Sunde, 2009), estimation of the effect of agricultural land use on the distribution of the Common Buzzard and Common Kestrel (Falco tinnunculus) (Butet et al., 2010). The present study is the first one of this kind for the territory of the Donetsk Ridge.

\section{Material and methods}

The data on the number of the raptors were collected on walking routes and car routes in accordance with the recommendations on the recording of raptors and the processing of primary data (Karyakin, 2000). The comparative analysis of the changes in the numbers of the raptors in the region was based on the literature data. In the nonbreeding season (October - March), special attention was paid to the search for nests that potentially belonged to raptor species, with their subsequent examination in the nesting period, in accordance with the methodological recommen- 
dations for the monitoring program of birds of prey in Ukraine (Gavrilyuk, 2009). For this, a continuous survey of the forests, mainly bayrak (steppe ravine), watershed and floodplain oak forests was carried out. For all the nests found, geographical coordinates were determined using a GPS navigator, the location of the nests was plotted on a topographic basis with the maximum degree of accuracy using NextGIS Mobile software.

The studies were conducted in 1999-2019. The total length of the walking routes was $2,864 \mathrm{~km}$ while a distance of $1,548 \mathrm{~km}$ was covered by car routes. The total of 393 field days was spent. 306 nests of birds of prey or those potentially belonging to members of this group were found and re-examined.

The boundaries of the nesting territories and home ranges were determined by the data of the encounters with the raptors and findings of their nests. The habitat composition and area within the nesting territories and home ranges and the distance to human settlements were estimated using the QGIS program. The home range includes nesting territory and all those areas where the birds hunt (Galushin, 1971; Newton, 1979).

The selectivity for the areas with varying degrees of the anthropogenic transformation was estimated by comparing the home ranges and territories occupied by the raptors with randomly selected territories within the Donetsk Ridge. For this, the selectivity index of V.S. Ivlev (1955) modified by Jacobs (1974) was used:

$$
E=\frac{r-p}{r+p-2 r p},
$$

where $\mathrm{E}$ - selectivity index for the resource in question; $r$ - share of the resource among the resources used by the species; $p$ - the share of the same resource among available resources in the environment.

The index can range from -1 (avoidance) to +1 (preference); a value of zero corresponds to a lack of selectivity.

By the concept of "anthropogenic disturbance" we understand the degree of the human impact on ecosystems. The anthropogenic disturbance includes the use of animal and plant resources (hunting, fishing, tree felling, harvesting of medicinal herbs), grazing, haying, recreational load, pollution (discharge of industrial and domestic wastewater into the water bodies, emissions of pollutants into the atmosphere), conversion of certain areas into arable lands and the radical transformation of the landscapes (residential and industrial development, quarrying, the creation of slagheaps, filling sludge collectors etc.).

The coefficient of the anthropogenic transformation proposed by Shishchenko (1988) was used to estimate whether the raptors prefer or avoid the areas transformed by the human impact. Each type of a land use within the geosystem is assigned a certain score depending on the degree of the impact of human activity. Taking into account these scores and the specific areas of land used in one way or another, an indicator is derived that reflects the degree of transformation of landscape complexes as a whole.

For each habitat or habitat complex that was identified its own rank of transformation ( $\mathrm{r}$ ) was determined: forests -2 ; swamps, reed thickets, chalk slopes, ravines, hollows, rock outcrops -3 ; meadows, steppes -4 ; gardens, city parks, forest parks, squares, alleys, boulevards - 5; agroecosystems -6 ; one-storey buildings, farms, cemeteries -7 ; multi-storey buildings -8 ; canals, reservoirs and coolers of thermal power plants -9 ; industrial lands -10 .

The transformation depth index (q) was adopted for: conservation areas - 1.00; forests -1.05 ; swamps, reed thickets, chalk slopes, ravines, hollows, outcrops -1.10 ; meadows, steppes -1.15 ; gardens, city parks, forest parks, squares, alleys, boulevards - 1.20; agroecosystems -1.25 ; one-storey buildings, farms, cemeteries -1.30 ; multi-storey buildings 1.35; canals, reservoir and coolers of thermal power plants - 1.40; industrial lands -1.50 . The coefficient of the anthropogenic transformation was calculated by the formula (Shishchenko, 1988):

$$
\mathrm{K}_{\mathrm{an}}=\sum\left(\mathrm{r}_{\mathrm{i}} \mathrm{p}_{\mathrm{i}} \mathrm{q}_{\mathrm{i}}\right) / 100 \text {, }
$$

where $r_{i}$ is a rank of the transformation of $i$ habitat; $p_{i}$ is the area of the habitat with a given transformation rank ( $\%$ of the total area); $q_{i}$ is the habitat transformation depth index. Five grades of habitat transformation were distinguished according to the level of anthropogenic disturbance and based on the Kan values: very slightly changed (2.00-3.80), slightly changed (3.81-5.30), moderately changed (5.31-6.50), highly modified (6.51-7.50), very strongly modified (more than 7.51 ). The distribution of the raptor species by the faunistic complexes and ecological groups is given in accordance with the classification of Belik (2000).

\section{Results}

The dynamics of the population of raptors of the Donetsk ridge along the gradient of anthropogenic disturbance. The species composition and abundance of the raptors of the Donetsk Ridge underwent significant changes over the course of 200 years (Table 1).

The formation of the fauna and population dynamics of the diurnal birds of prey of the Donetsk Ridge was apparently marked by the process of adaptation (or failing to adapt) of individual species to the anthropogenic transformation of the landscape from complete extinction (zero level of adaptation) to the formation of completely flourishing populations (an increase in the level of the tolerance to human disturbance, synurbization).

One of the criteria for the tolerance of the raptors to human disturbance is the distance from their nesting territories to the settlements and roads. According to our calculations, the Eurasian Hobby (Falco subbuteo) settles most distantly from human residential buildings. Despite the fact that one nest of this raptor was found in an urban area (such a case was a single and probably an exception), on average, the nests and nesting territories of the Eurasian Hobby were located at a distance of 3,568 $\pm 1,626 \mathrm{~m}(\mathrm{n}=4)$ from the nearest residential building.

The species ranged by the remoteness of their nests from human habitation as follows: White-tailed Eagle (Haliaetus albicilla) $(2,714 \pm 476 \mathrm{~m}$, $\mathrm{n}=7$ ), Short-toed Eagle (Circaetus gallicus) $(2,293 \pm 402 \mathrm{~m}, \mathrm{n}=2)$, Northern Goshawk $(1,768 \pm 102 \mathrm{~m}, \mathrm{n}=75)$, Booted Eagle (Hieraaetus pennatus $)(1,767 \pm 264 \mathrm{~m}, \mathrm{n}=19)$, Common Buzzard $(1,644 \pm 101 \mathrm{~m}, \mathrm{n}=$ 64), Long-legged Buzzard (Buteo rufinus) $(1,559 \pm 193 \mathrm{~m}, \mathrm{n}=4)$, European Honey Buzzard (Pernis apivorus) $(1,291 \pm 780 \mathrm{~m}, \mathrm{n}=2)$, Saker Falcon (Falco cherrug) $(973 \mathrm{~m} \mathrm{n}=1)$, Eastern Imperial Eagle (Aquila heliaca) $(921 \pm 214 \mathrm{~m} \mathrm{n}=6)$, Eurasian Sparrowhawk (Accipiter nisus) (892 $\pm 192 \mathrm{~m}, \mathrm{n}=13)$, Black Kite (Milvus migrans) $(742 \pm 103 \mathrm{~m}, \mathrm{n}=$ 14), Common Kestrel (645 $\pm 219 \mathrm{~m}, \mathrm{n}=15)$, Red-footed Falcon (Falco vespertinus) $(403 \pm 18 \mathrm{~m}, \mathrm{n}=2)$, Lesser Kestrel (Falco naumanni) $(247 \mathrm{~m}, \mathrm{n}=1)$.

The Long-legged Buzzard and the White-tailed Eagle most consistently avoided urban and rural buildings. We didn't find their nests closer than $1,000 \mathrm{~m}$ from the borders of the urban areas. The Booted Eagle placed its nests at a distance of $400-500 \mathrm{~m}$ from the settlement areas. The Black Kite, the Common Buzzard, and the Northern Goshawk nested no closer than $200-300 \mathrm{~m}$ to the city limits. Nesting territories of the Eurasian Sparrowhawk, Eurasian Hobby and Common Kestrel were found directly in the large cities (Kramatorsk, Donetsk, Makeevka, Lugansk) (Table 2).

Most often, the raptors visit the settlements of the Donetsk Ridge for hunting or resting during migration. According to our data, the Black Kite, the Western Marsh Harrier (Circus aeruginosus), the Eurasian Sparrowhawk and the Common Kestrel are clearly attracted to the settlements. The proportion of the occurrence of these species in urban areas is the largest (Table 2). The apparent avoidance of any urban areas is observed in the Booted Eagle.

Anthropogenic disturbance is minimal within the protected areas. Here the proportion of the occurrence of the raptors found was quite large. The protected areas are of uttermost importance for the Black Kite, the Booted Eagle and the White-tailed Eagle. More than $50 \%$ of all raptors' nests were found within the protected areas.

The habitat structure of the nesting territories and home ranges. The habitat structure of the nesting territories is quite diverse in different species of the diurnal birds of prey. This is especially noticeable in the ratio of forest and grassland habitats. Based on the selectivity index, we found that the vast majority of the raptors of the Donetsk Ridge prefer temperate broad-leaved forests when choosing nesting territories (Table 3). Temperate coniferous forests are preferred by the European Honey Buzzard, Northern Goshawk, White-tailed Eagle, and Eurasian Hobby. Western Marsh Harrier, Montagu's Harrier (Circus pygargus) and Common Kestrel avoid any forest habitats.

Positive selectivity for the shrublands was observed in the Eurasian Sparrowhawk and Montagu's Harrier. Although wetlands play an important role in the life of birds of prey, these habitats were within the nesting territories of only four species, and in those of two more species, the Eurasian Hobby and the Northern Goshawk, the wetlands were found only by 
chance. The Black Kite often nests on trees that grow along the banks of the rivers, lakes or artificial ponds within the forest matrix and the Western Marsh Harrier builds nests exclusively on ponds overgrown with the reeds. All harrier species, the Black Kite, and the White-tailed Eagle apparently prefer water bodies and meadow habitats as parts of their nesting territories. The Common Kestrel prefers residential areas when choosing a nesting territory. An important adaptation of birds of prey is breeding in old nests of corvids on the towers of power transmissions lines (e.g. the Eastern Imperial Eagle, the Saker Falcon, the Eurasian Hobby and the Common Kestrel).

Table 1

The dynamics of the number of raptors of the Donetsk Ridge in 1800-2019

\begin{tabular}{|c|c|c|c|c|c|c|c|c|c|c|c|}
\hline \multirow[b]{2}{*}{ Species } & \multirow[b]{2}{*}{ 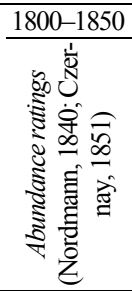 } & \multicolumn{2}{|c|}{$1850-1900$} & \multicolumn{2}{|c|}{$1900-1950$} & \multicolumn{2}{|c|}{$1950-1980$} & \multicolumn{2}{|c|}{$1980-2000$} & \multicolumn{2}{|c|}{$2000-2019$} \\
\hline & & 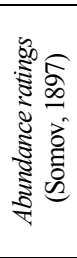 & 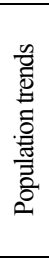 & 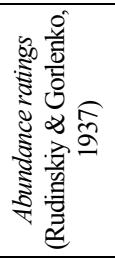 & 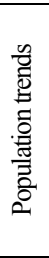 & 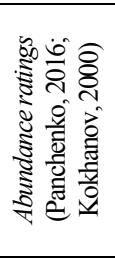 & 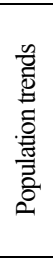 & 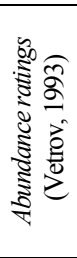 & 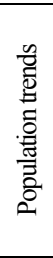 & 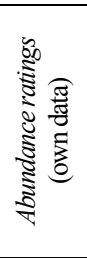 & 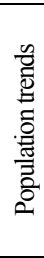 \\
\hline Pandion haliaetus (Linnaeus, 1758) & $\mathrm{R}$ & $\mathrm{F}$ & $\uparrow$ & $\mathrm{R}$ & $\downarrow$ & $\mathrm{R}$ & $\Delta$ & $\mathrm{R}$ & $\leftrightarrow$ & $\mathrm{R}$ & $\leftrightarrow$ \\
\hline Pernis apivorus (Linnaeus, 1758) & $\mathrm{R}$ & $\mathrm{F}$ & $\uparrow$ & $\mathrm{O}$ & $\downarrow$ & $\mathrm{R}$ & $\downarrow$ & $\mathrm{O}$ & $\uparrow$ & $\mathrm{R}$ & $\downarrow$ \\
\hline Milvus migrans (Boddaert, 1783) & $\mathrm{F}$ & $\mathrm{F}$ & $\leftrightarrow$ & $\mathrm{F}$ & $\leftrightarrow$ & $\mathrm{F}$ & $\leftrightarrow$ & $\mathrm{F}$ & $\leftrightarrow$ & $\mathrm{O}$ & $\downarrow$ \\
\hline Circus cyaneus (Linnaeus, 1766) & A & $\mathrm{F}$ & $\downarrow$ & $\mathrm{F}$ & $\leftrightarrow$ & $\mathrm{R}$ & $\boldsymbol{\Delta}$ & $\mathrm{R}$ & $\leftrightarrow$ & $\mathrm{O}$ & $\uparrow$ \\
\hline C. macrourus S. G. Gmelin, 1770 & A & $\mathrm{F}$ & $\downarrow$ & $\mathrm{F}$ & $\leftrightarrow$ & $\mathrm{R}$ & $\downarrow$ & $\mathrm{R}$ & $\boldsymbol{\Delta}$ & $\mathrm{R}$ & $\leftrightarrow$ \\
\hline C. pygargus (Linnaeus, 1758) & A & $\mathrm{F}$ & $\downarrow$ & $\mathrm{F}$ & $\leftrightarrow$ & $\mathrm{R}$ & $\downarrow$ & $\mathrm{R}$ & $\leftrightarrow$ & $\mathrm{O}$ & $\uparrow$ \\
\hline C. aeruginosus (Linnaeus, 1758) & A & $\mathrm{F}$ & $\downarrow$ & $\mathrm{F}$ & $\leftrightarrow$ & $\mathrm{O}$ & $\downarrow$ & $\mathrm{O}$ & $\leftrightarrow$ & A & $\uparrow$ \\
\hline Accipiter gentilis (Linnaeus, 1758) & $\mathrm{F}$ & $\mathrm{F}$ & $\downarrow$ & $\mathrm{O}$ & $\downarrow$ & $\mathrm{F}$ & $\uparrow$ & $\mathrm{O}$ & $\downarrow$ & $\mathrm{F}$ & $\uparrow$ \\
\hline A. nisus (Linnaeus, 1758) & $\mathrm{F}$ & $\mathrm{O}$ & $\downarrow$ & $\mathrm{F}$ & $\uparrow$ & $\mathrm{F}$ & $\leftrightarrow$ & $\mathrm{R}$ & $\downarrow$ & $\mathrm{O}$ & $\uparrow$ \\
\hline A. brevipes (Severtzov, 1850) & $\mathrm{R}$ & $\mathrm{F}$ & $\uparrow$ & $\mathrm{O}$ & $\downarrow$ & $\mathrm{R}$ & $\downarrow$ & $\mathrm{R}$ & $\leftrightarrow$ & $\mathrm{R}$ & $\leftrightarrow$ \\
\hline Buteo lagopus (Pontoppidan, 1763) & A & $\mathrm{F}$ & $\downarrow$ & $\mathrm{F}$ & $\leftrightarrow$ & $\mathrm{F}$ & $\leftrightarrow$ & $\mathrm{F}$ & $\leftrightarrow$ & A & $\uparrow$ \\
\hline B. rufinus (Cretzschmar, 1829) & - & $\mathrm{R}$ & $\bullet$ & $\mathrm{R}$ & $\leftrightarrow$ & - & $\boldsymbol{\Delta}$ & $\mathrm{R}$ & $\uparrow$ & $\mathrm{R}$ & $\bullet$ \\
\hline B. buteo (Linnaeus, 1758) & $\mathrm{R}$ & $\mathrm{F}$ & $\uparrow$ & $\mathrm{F}$ & $\leftrightarrow$ & $\mathrm{O}$ & $\downarrow$ & $\mathrm{F}$ & $\uparrow$ & A & $\uparrow$ \\
\hline Circaetus gallicus (Gmelin, 1788) & $\mathrm{R}$ & $\mathrm{R}$ & $\leftrightarrow$ & $\mathrm{R}$ & $\leftrightarrow$ & - & $\downarrow$ & $\mathrm{R}$ & $\uparrow$ & - & $\boldsymbol{\Delta}$ \\
\hline Hieraaetus pennatus (Gmelin, 1788) & $\mathrm{F}$ & $\mathrm{F}$ & $\leftrightarrow$ & $\mathrm{F}$ & $\leftrightarrow$ & $\mathrm{R}$ & $\downarrow$ & $\mathrm{O}$ & $\uparrow$ & $\mathrm{O}$ & $\leftrightarrow$ \\
\hline Aquila nipalensis (Hodgson, 1833) & $\mathrm{F}$ & $\mathrm{R}$ & $\downarrow$ & $\mathrm{O}$ & $\uparrow$ & $\mathrm{R}$ & $\boldsymbol{\Delta}$ & $\mathrm{R}$ & $\leftrightarrow$ & - & - \\
\hline Clanga clanga (Pallas, 1811) & $\mathrm{F}$ & $\mathrm{R}$ & $\downarrow$ & $\mathrm{O}$ & $\uparrow$ & $\mathrm{F}$ & $\uparrow$ & $\mathrm{R}$ & $\boldsymbol{\Delta}$ & $\mathrm{R}$ & $\leftrightarrow$ \\
\hline C. pomarina Brehm, 1831 & - & - & - & - & - & $\mathrm{R}$ & $\bullet$ & $\mathrm{R}$ & $\leftrightarrow$ & $\mathrm{R}$ & $\leftrightarrow$ \\
\hline A. heliaca Savigny, 1809 & $\mathrm{~F}$ & $\mathrm{~F}$ & $\downarrow$ & $\mathrm{O}$ & $\downarrow$ & $\mathrm{R}$ & $\downarrow$ & $\mathrm{R}$ & $\leftrightarrow$ & $\mathrm{R}$ & $\leftrightarrow$ \\
\hline A. chrysaetos (Linnaeus, 1758) & $\mathrm{F}$ & $\mathrm{R}$ & $\downarrow$ & $\mathrm{R}$ & $\leftrightarrow$ & $\mathrm{R}$ & $\leftrightarrow$ & $\mathrm{R}$ & $\leftrightarrow$ & $\mathrm{R}$ & $\leftrightarrow$ \\
\hline Haliaetus albicilla (Linnaeus, 1758) & $\mathrm{F}$ & $\mathrm{F}$ & $\leftrightarrow$ & $\mathrm{O}$ & $\downarrow$ & $\mathrm{R}$ & $\downarrow$ & $\mathrm{R}$ & $\leftrightarrow$ & $\mathrm{R}$ & $\leftrightarrow$ \\
\hline Neophron percnopterus (Linnaeus, 1758) & - & $\mathrm{R}$ & - & - & - & - & - & - & - & - & - \\
\hline Aegypius monachus (Linnaeus, 1766) & - & $\mathrm{R}$ & - & - & - & - & - & - & - & - & - \\
\hline Gyps fulvus (Hablitz, 1783) & $\mathrm{F}$ & $\mathrm{F}$ & $\leftrightarrow$ & - & - & $\mathrm{R}$ & $\downarrow$ & $\mathrm{R}$ & $\leftrightarrow$ & - & - \\
\hline Falco rusticolus Linnaeus, 1758 & - & $\mathrm{R}$ & - & - & - & $\mathrm{R}$ & $\uparrow$ & & - & - & - \\
\hline F. cherrug Gray, 1834 & $\mathrm{R}$ & $\mathrm{F}$ & $\uparrow$ & $\mathrm{O}$ & $\downarrow$ & $\mathrm{F}$ & $\uparrow$ & $\mathrm{R}$ & $\boldsymbol{\Delta}$ & $\mathrm{R}$ & $\bullet$ \\
\hline F. peregrinus Tunstall, 1771 & $\mathrm{~F}$ & $\mathrm{R}$ & $\downarrow$ & $\mathrm{R}$ & $\leftrightarrow$ & $\mathrm{R}$ & $\leftrightarrow$ & $\mathrm{R}$ & $\leftrightarrow$ & $\mathrm{R}$ & $\leftrightarrow$ \\
\hline F. subbuteo Linnaeus, 1758 & $\mathrm{~F}$ & A & $\uparrow$ & $\mathrm{F}$ & $\downarrow$ & $\mathrm{F}$ & $\leftrightarrow$ & $\mathrm{O}$ & $\downarrow$ & $\mathrm{O}$ & $\leftrightarrow$ \\
\hline Falco columbarius Linnaeus, 1758 & $\mathrm{~F}$ & $\mathrm{R}$ & $\downarrow$ & $\mathrm{R}$ & $\leftrightarrow$ & $\mathrm{R}$ & $\leftrightarrow$ & $\mathrm{O}$ & $\uparrow$ & $\mathrm{R}$ & $\downarrow$ \\
\hline F. vespertinus Linnaeus, 1766 & $\mathrm{~F}$ & A & $\uparrow$ & A & $\leftrightarrow$ & A & $\leftrightarrow$ & $\mathrm{F}$ & $\downarrow$ & $\mathrm{R}$ & $\downarrow$ \\
\hline F. naumanni Fleischer, 1818 & - & $\mathrm{R}$ & $\bullet$ & $\mathrm{F}$ & $\uparrow$ & $\mathrm{R}$ & $\downarrow$ & $\mathrm{R}$ & $\leftrightarrow$ & - & $\boldsymbol{\Delta}$ \\
\hline F. tinnunculus Linnaeus, 1758 & A & A & $\leftrightarrow$ & A & $\leftrightarrow$ & A & $\leftrightarrow$ & $\mathrm{F}$ & $\downarrow$ & $\mathrm{F}$ & $\leftrightarrow$ \\
\hline
\end{tabular}

Note: abundance ratings (Morris, 1995): A - the species is abundant in a given area; $\mathrm{F}$ - the species is frequent in a given area; $\mathrm{O}-$ the species is occasional in a given area; $\mathrm{R}$ - the species is rare in a given area; “- “- no data; population trends: $\uparrow$ - increasing; $\downarrow$ - decreasing; $\leftrightarrow-$ stable; $\boldsymbol{\Delta}$ - disappeared as breeding species; $\bullet-$ resumed breeding; “-"“-no data.

Table 2

The occurrence $(\%)$ of the raptors in different types of human settlements

\begin{tabular}{lccccc}
\hline \multicolumn{1}{c}{ Species } & City & Town & $\begin{array}{c}\text { Rural } \\
\text { town }\end{array}$ & Village & $\begin{array}{c}\text { Number of } \\
\text { registrations }\end{array}$ \\
\hline Milvus migrans & 8.0 & 36.0 & 52.0 & 4.0 & 25 \\
Circus pygargus & 7.7 & 30.8 & 61.5 & 0.0 & 13 \\
C. aeruginosus & 2.6 & 38.2 & 59.2 & 0.0 & 76 \\
Accipiter gentilis & 13.7 & 33.4 & 49.0 & 3.9 & 51 \\
A. nisus & 46.8 & 18.8 & 31.3 & 3.1 & 32 \\
Buteo rufinus & 9.1 & 9.1 & 81.8 & 0.0 & 11 \\
B. buteo & 4.6 & 51.8 & 41.2 & 2.4 & 85 \\
Hieraaetus pennatus & 0.0 & 28.6 & 71.4 & 0.0 & 7 \\
Haliaetus albicilla & 0.0 & 50.0 & 50.0 & 0.0 & 6 \\
Falco vespertinus & 33.3 & 33.3 & 33.4 & 0.0 & 3 \\
F. subbuteo & 0.0 & 0.0 & 100.0 & 0.0 & 7 \\
F. tinnunculus & 42.9 & 7.1 & 46.4 & 3.6 & 28 \\
\hline
\end{tabular}

Note: data was collected in 1999-2019 in settlements within the Donetsk Ridge.

The landscape elements of various natural zones create a habitat mosaic that determines the birds' choice of home range. All the noted species, except the Western Marsh Harrier and the Common Kestrel, depend at least at some extent on forest or shrubby habitats. The wetlands are clearly preferred by the White-tailed Eagle, the Eurasian Sparrowhawk and the Montagu's Harrier, but most of all by the Black Kite and the Western Marsh Harrier (Table 4). The preference for open areas is well-pronounced in the Montagu's Harrier and the Red-footed Falcon. Slight selectivity for these habitats was observed in the Long-legged Buzzard and the Common Kestrel. All species, except the Western Marsh Harrier, when choosing home ranges, avoid the proximity of human settlements and those areas which are heavily transformed by human activities.

Very strongly modified and highly modified landscapes dominated throughout a significant part of the Donetsk Ridge. The share of slightly changed areas does not exceed 14\% of the area of the Donetsk Ridge, and the share of very slightly changed areas is less than $4 \%$.

The species with the highest demands for the virgin habitats were the European Honey Buzzard, the Northern Goshawk, the Booted Eagle, the White-tailed Eagle, and the Eurasian Hobby. More than $75 \%$ of the nesting territories of these species were comprised by very slightly changed habitats (anthropogenic transformation coefficient 2.10-3.61) (Table 5). The proportion of the nesting territories of the same species located in slightly changed habitats (anthropogenic transformation coefficient 3.974.72) ranged from 4 to $25 \%$. 
About $75 \%$ of the nesting territories of the Black Kite, the Eurasian Sparrowhawk, the Long-legged Buzzard, and the Red-footed Falcon were located in very slightly and slightly changed habitats. The nesting territories of the Common Kestrel were located overwhelmingly in highly modified $(20 \%)$ and very strongly modified habitats $(60 \%)$. In the Black Kite and the Western Marsh Harrier, the proportion of the nesting territories in highly modified habitats did not exceed $22 \%$.

Table 3

The habitat selectivity of the birds of prey for the nesting territories

\begin{tabular}{|c|c|c|c|c|c|c|c|c|c|}
\hline \multirow[b]{2}{*}{ Species } & \multicolumn{9}{|c|}{ Ivlev-Jacobs selectivity index for the habitats } \\
\hline & 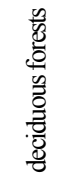 & 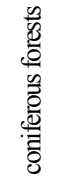 & 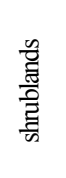 & $\begin{array}{l}\frac{n}{0} \\
\text { 퓰 } \\
\vdots\end{array}$ & 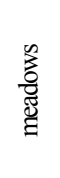 & $\begin{array}{l}\frac{y}{0} \\
\frac{0}{2}\end{array}$ & 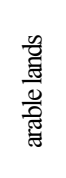 & 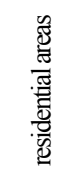 & 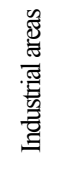 \\
\hline Pernis apivorus & 0.91 & 0.69 & -1.00 & -1.00 & -0.51 & -0.51 & 0.79 & 0.97 & -1.00 \\
\hline Milvus migra & 0.82 & -0.05 & -1.00 & 0.87 & 0.18 & -0.74 & -0.75 & -1.00 & -1.00 \\
\hline Circus pygargus & -0.19 & -1.00 & 0.63 & -1.00 & 0.66 & -0.18 & 0.20 & -1.00 & -1.00 \\
\hline C. aeruginosus & -0.90 & -1.00 & -1.00 & 0.99 & 0.70 & -0.93 & -0.99 & -0.75 & -1.00 \\
\hline Accipiter gentilis & 0.97 & 0.15 & 0.72 & -0.91 & -0.87 & -0.89 & -0.86 & -1.00 & -1.00 \\
\hline A. nisus & 0.79 & 0.77 & -1.00 & -1.00 & 0.29 & -0.52 & -0.64 & -0.52 & -0.29 \\
\hline Buteo rufinus & 0.95 & -1.00 & -1.00 & -1.00 & -1.00 & -0.43 & 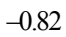 & -1.00 & -1.00 \\
\hline B. buteo & 0.93 & -0.47 & -1.00 & -1.00 & -0.56 & -0.42 & -0.73 & -0.99 & -1.00 \\
\hline Hieraaetus pennatus & 0.97 & -0.02 & -1.00 & -1.00 & -1.00 & -0.98 & -0.84 & -1.00 & -1.00 \\
\hline Haliaetus albicilla & 0.73 & 0.95 & -1.00 & -1.00 & 0.27 & -0.66 & -0.87 & -1.00 & -1.00 \\
\hline Falco subbuteo & 0.95 & 0.72 & -1.00 & -0.77 & 0.27 & -1.00 & -18 & -1.00 & -1.00 \\
\hline & 0.75 & -1.00 & 0.95 & -1.00 & -1.00 & $-0.1 \mathrm{c}$ & -0.2 & -1.0 & -1.00 \\
\hline F. tinnunculus & -0.74 & -1.00 & -1.00 & -1.00 & -0.36 & 0.49 & -0.68 & 0.69 & -1.00 \\
\hline
\end{tabular}

Note: the index can range from -1 (avoidance) to +1 (preference); a value of zero corresponds to a lack of selectivity.

Table 4

The habitat selectivity of the birds of prey for the home ranges

\begin{tabular}{lcccc}
\hline \multirow{2}{*}{ species } & \multicolumn{3}{c}{ Ivlev-Jacobs selectivity index for the habitats } \\
\cline { 2 - 5 } & forests & wetlands & $\begin{array}{c}\text { open } \\
\text { habitats }\end{array}$ & $\begin{array}{c}\text { human } \\
\text { settlements }\end{array}$ \\
\hline Pernis apivorus & 0.49 & 0.06 & -0.17 & -0.50 \\
Milvus migrans & 0.48 & 0.55 & -0.28 & -0.36 \\
Circus pygargus & 0.17 & 0.37 & 0.10 & -0.55 \\
C. aeruginosus & -0.60 & 0.93 & -0.46 & 0.04 \\
Accipiter gentilis & 0.76 & -0.42 & -0.52 & -0.50 \\
A. nisus & 0.60 & 0.24 & -0.38 & -0.26 \\
Buteo rufinus & 0.30 & -0.75 & 0.02 & -0.37 \\
B. buteo & 0.53 & -0.78 & -0.14 & -0.65 \\
Hieraaetus pennatus & 0.48 & -0.05 & -0.17 & -0.43 \\
Haliaetus albicilla & 0.85 & 0.37 & -0.68 & -0.84 \\
Falco subbuteo & 0.93 & 0.17 & -0.84 & -0.90 \\
F. vespertinus & 0.11 & -1.00 & 0.35 & -0.81 \\
F. tinnunculus & -0.15 & 0.59 & 0.01 & -0.09 \\
\hline
\end{tabular}

Note: the index can range from -1 (avoidance) to +1 (preference); a value of zero corresponds to a lack of selectivity.

Table 5

The distribution of the nesting territories (\%) of the birds of prey of the Donetsk Ridge along the gradient of anthropogenic disturbance

\begin{tabular}{lccccc}
\hline \multirow{2}{*}{\multicolumn{1}{c}{ Species }} & $\begin{array}{c}\text { very } \\
\text { slightly } \\
\text { changed }\end{array}$ & $\begin{array}{c}\text { slightly } \\
\text { changed }\end{array}$ & $\begin{array}{c}\text { moder- } \\
\text { ately } \\
\text { changed }\end{array}$ & $\begin{array}{c}\text { highly } \\
\text { modified }\end{array}$ & $\begin{array}{c}\text { very } \\
\text { strongly } \\
\text { modified }\end{array}$ \\
\hline Pernis apivorus & 75.0 & 25.0 & 0.0 & 0.0 & 0.0 \\
Milvus migrans & 50.0 & 25.0 & 6.3 & 18.7 & 0.0 \\
Circus pygargus & 0.0 & 50.0 & 0.0 & 50.0 & 0.0 \\
C. aeruginosus & 28.6 & 35.7 & 7.1 & 21.5 & 7.1 \\
Accipiter gentilis & 96.0 & 4.0 & 0.0 & 0.0 & 0.0 \\
A. nisus & 43.8 & 31.3 & 12.5 & 12.5 & 0.0 \\
Buteo rufinus & 50.0 & 25.0 & 25.0 & 0.0 & 0.0 \\
B. buteo & 85.0 & 15.0 & 0.0 & 0.0 & 0.0 \\
Hieraaetus pennatus & 90.0 & 10.0 & 0.0 & 0.0 & 0.0 \\
Haliaetus albicilla & 83.3 & 0.0 & 16.7 & 0.0 & 0.0 \\
Falco subbuteo & 60.0 & 20.0 & 0.0 & 0.0 & 20.0 \\
F. vespertinus & 25.0 & 50.0 & 25.0 & 0.0 & 0.0 \\
F. tinnunculus & 0.0 & 20.0 & 0.0 & 20.0 & 60.0 \\
$\quad$ Test sites & 3.5 & 13.8 & 17.2 & 51.7 & 13.8 \\
\hline
\end{tabular}

The Montagu's Harrier equally successfully occupies both slightly changed and highly modified areas (anthropogenic transformation coefficient 3.81-5.30 and 6.51-7.50). The nesting territories of the Common Kestrel were in highly modified and very strongly modified habitats ( $20 \%$ and $60 \%$, respectively). The nesting territories of the Black Kite, the Western Marsh Harrier, and the Eurasian Hobby also were found within highly modified habitats although the share of such nesting territories in these species didn't exceed $22 \%$.

All the home ranges of the Eurasian Hobby (with the exception of those found in the urban area) and more than $80 \%$ of the home ranges of the White-tailed Eagle were located within slightly changed and very slightly changed habitats (Table 6).

Table 6

The distribution of the home ranges (\%) of the birds of prey of the Donetsk Ridge along the gradient of anthropogenic disturbance

\begin{tabular}{lccccc}
\hline \multirow{1}{*}{ Species } & \multicolumn{5}{c}{ Home ranges } \\
\cline { 2 - 6 } & $\begin{array}{c}\text { very slightly } \\
\text { changed }\end{array}$ & $\begin{array}{c}\text { slightly } \\
\text { changed }\end{array}$ & $\begin{array}{c}\text { moderately } \\
\text { changed }\end{array}$ & $\begin{array}{c}\text { highly } \\
\text { modified }\end{array}$ & $\begin{array}{c}\text { very } \\
\text { strongly } \\
\text { modified }\end{array}$ \\
\hline Pernis apivorus & 50.0 & 14.3 & 21.4 & 14.3 & 0.0 \\
Milvus migrans & 29.6 & 25.9 & 33.3 & 7.5 & 3.7 \\
Circus pygargus & 0.0 & 16.7 & 50.0 & 33.3 & 0.0 \\
C. aeruginosus & 0.0 & 26.7 & 33.3 & 33.3 & 6.7 \\
Accipiter gentilis & 43.8 & 34.2 & 18.7 & 3.3 & 0.0 \\
A. nisus & 23.5 & 17.7 & 41.1 & 5.9 & 11.8 \\
Buteo rufinus & 0.0 & 0.0 & 60.0 & 40.0 & 0.0 \\
B. buteo & 23.1 & 48.7 & 25.6 & 2.6 & 0.0 \\
Hieraaetus pennatus & 28.6 & 21.4 & 35.7 & 14.3 & 0.0 \\
Haliaetus albicilla & 66.6 & 16.7 & 16.7 & 0.0 & 0.0 \\
Falco subbuteo & 60.0 & 0.0 & 20.0 & 20.0 & 0.0 \\
F. vespertinus & 0.0 & 50.0 & 50.0 & 0.0 & 0.0 \\
F. tinnunculus & 0.0 & 40.0 & 10.0 & 20.0 & 30.0 \\
Test sites & 3.5 & 13.8 & 17.2 & 51.7 & 13.8 \\
\hline
\end{tabular}

The home ranges of the European Honey Buzzard, the Black Kite, the Northern Goshawk, the Common Buzzard, the Booted Eagle, the White-tailed Eagle, and the Eurasian Hobby were within very slightly changed and slightly changed habitats (Table 6). Only in the Northern Goshawk, the Common Buzzard and the White-tailed Eagle were more than $70 \%$ of the home ranges in very slightly changed and slightly changed habitats. The proportion of the home ranges within very slightly changed and slightly changed habitats ranges from 50 to $70 \%$ in the European Honey Buzzard, the Booted Eagle, the Eurasian Hobby, and the Red-footed Falcon.

However, some home ranges of the European Honey Buzzard, the Black Kite, the Northern Goshawk, the Booted Eagle, the Common Buzzard, the Red-footed Falcon, and the Eurasian Hobby were found within the moderately changed to highly modified habitat matrix.

The home ranges of the Black Kite and the Eurasian Sparrowhawk were found in mosaics of habitats of all five gradations of anthropogenic transformation.

The home ranges of the Common Kestrel were located in highly modified and very strongly modified habitat mosaics $(50 \%)$. Outside large cities, most of the home ranges of the Common Kestrel were located in moderately and slightly changed mosaics of biotopes.

\section{Discussion}

The long-term dynamics of the Falconiformes population was characterized by a general decline in the numbers of most species (Nordmann, 1840; Czernay, 1851; Somov, 1897; Rudinskiy \& Gorlenko, 1937) (Table 1). Noteworthy is the increase in the number of species which experienced a decreasing trend in numbers in the 1950s and 1980s (Panchenko, 2016; Kokhanov, 2000). During this period, four species of raptors ceased to breed within the territory of the Donetsk Ridge. Another five species were not recorded at former breeding sites in the study area in 1980-2019 (Vetrov, 1993). Over the past 20 years, increasing trends have been observed in the dynamics of the number of species and in the abundance of raptors e.g. two new species appeared as breeding birds and the numbers of six species rose. A decreasing trend in numbers was observed in three species in 2000-2019, and a stable abundance was recorded for 
six species. Over the course of two centuries, there has been an increase in the participation of dendrophilous species, and a decrease in campophiles and sclerophiles. Limnophiles were continously represented during the entire observation period by one species. The long-term dynamics of the species composition of the raptors of the Donetsk Ridge was reflected in the changes of the distribution of the representativeness of various faunistic complexes and faunistic groups. There was a loss of representatives of the boreal and desert-steppe faunistic complexes and simultaneous increase in the participation of representatives of the nemoral and forest steppe faunistic complexes associated with the floodplain forests of the Siversky Donets River valley and the bayrak oak forests of the central part of the Donetsk Ridge.

The industrial development of the territory of the Donetsk ridge led principally to the disappearance of the steppe species of the birds of prey e.g. the Pallid Harrier (Circus macrourus), the Steppe Eagle (Aquila nipalensis) and the Lesser Kestrel or species intolerant of the presence of humans e.g. the Osprey (Pandion haliaetus), the Short-toed Eagle, the Greater Spotted Eagle (Aquila clanga). Dendrophiles were better adapted than others to the changes in the environment. The forest planting in the steppe within the Donetsk Ridge contributed to the formation of the forest steppe fauna of the birds of prey. The Northern Goshawk, the Common Buzzard and the Booted Eagle readily use artificial forests of non-belt configuration for breeding. The abundance of some forest and forest steppe species, e.g. the Northern Goshawk and the Booted Eagle, is higher within the Donetsk Ridge than in other steppe regions (Kharkiv, Zaporizhia regions) (Milobog, 2012).

The impact of the anthropogenic factor on the dynamics of the population of the birds of prey is ambiguous. For the species which are sensitive to changes in the environment, such as the European Honey Buzzard, the Northern Goshawk, the Merlin (Falco columbarius) - a non-breeding species and the Red-footed Falcon, a general negative dynamics of the populations is observed. The positive trend in the numbers of the Longlegged Buzzard and the Saker Falcon is linked to the expansion of the both species into the territory of the Donetsk Ridge. The spread of the Long-legged Buzzard is partially due to its habitat tolerance as it breeds not only in natural forests but also in forest belts within the study area. The expansion of the Saker Falcon is facilitated by the use of nest constructions of the corvids on the towers of power transmission lines. In the Common Kestrel, a decrease in the numbers in natural habitats was noted, which was compensated by the ability to synurbization. In urban landscapes a positive dynamic of the numbers of this species was observed. A positive population dynamic was apparent in recent years in those species which are relatively tolerant to the anthropogenic transformation of the environment (the Western Marsh Harrier, the Northern Goshawk, the Eurasian Sparrowhawk, and the Common Buzzard).

Selectivity for nesting territories and home ranges is apparent in all the birds of prey of the Donetsk ridge and it depends clearly on the extent of anthropogenic transformation of the habitats. A high degree of adaptability allows the Black Kite, the Western Marsh Harrier, the Eurasian Sparrowhawk and the Common Kestrel to settle in various transformed habitats.

The Montagu's Harrier, the Long-legged Buzzard and the Saker Falcon demonstrate also a significant degree of adaptability to anthropogenic influence. These species have lost undisturbed natural habitats due to the anthropogenic transformation of the territory of the Donetsk Ridge and are forced to settle in moderately changed, highly modified and very strongly modified habitats.

A tendency to synurbization is apparent in small-sized birds of prey (the Eurasian Sparrowhawk, the Eurasian Hobby and the Common Kestrel). Moreover, the Common Kestrel has formed quite large urban populations in recent years. One can distinguish a group of species that are most sensitive to the anthropogenic transformation of the environment. They consistently place nests and choose nesting territories and home ranges in very slightly and slightly modified habitats (the European Honey Buzzard, the White-tailed Eagle and the Eurasian Hobby). The Northern Goshawk, the Common Buzzard and the Booted Eagle are less sensitive to anthropogenic transformation. All species except the Common Kestrel avoid highly modified and very strongly modified habitats.

The information on the habitat distribution of the raptors of the Donetsk Ridge is quite consistent with the data obtained in the Nerusso-Des- nyansky Polesye (Romanov, 2005) and in the Bryanskiy Les nature reserve (Romanov \& Evstigneev, 2016). The Common Buzzard and the Northern Goshawk in the absence of old-growth forests switch to other forest types including artificial ones. A similar trend is observed for the European Honey Buzzard, which in recent years has begun to use the forests in the central regions of the Donetsk ridge, and has ceased to be a species exclusively of the Seversky Donets valley. The reduction of the areas occupied by old-growth forests on the territory of the Donetsk Ridge determined the disappearance of the Short-toed Eagle.

The majority of the forest species of raptors need open areas for hunting. The Eurasian Sparrowhawk, the Northern Goshawk and the Booted Eagle may hunt within forest matrix and thus the lack of open habitats isn't an unfavourable factor for these species. Open areas are essential parts of the home ranges of harriers (for the Western Marsh Harrier the presence of extensive reedbeds is important), because the birds use them both for nesting and hunting.

The irregular distribution of the transformed natural landscapes largely determined the spatial distribution of the birds of prey within the Donetsk Ridge, and the habitat composition within their nesting territories and home ranges. The structure of the home ranges of all forest species of diurnal birds of prey not only depends on the optimal ratio of open and forested areas but on the presence of the ecotones of considerable length which originated in the complex mosaics of habitat complexes.

\section{Conclusions}

The majority of the species of raptors of the Donetsk Ridge prefer very slightly changed habitats when choosing nesting territories. The exceptions are the Montagu's Harrier and the Common Kestrel. The Montagu's Harrier settles in slightly changed meadow habitats, and in the absence of suitable habitats, colonizes agricultural lands. The Common Kestrel is now more common in the large cities, where the transformation of the landscapes is very high.

The stable number of dendrophiles and the disappearance (decrease in number) of sclerophiles and campophiles indicates the least anthropogenic transformation of forest habitats and a radical transformation of open spaces - meadows and steppes. The most successful were eurytopic birds of prey and species with pronounced anthropotolerance.

A pronounced habitat tolerance contributed to the appearance of the Long-Legged Buzzard in the Donetsk ridge, which now breeds not only in natural forests but in artificial forest belts too. An important adaptation of the birds of prey is the breeding in old nests of corvids on the towers of power transmissions lines (e.g. the Eastern Imperial Eagle, the Saker Falcon, the Eurasian Hobby and the Common Kestrel). It's possible that in the future some new species of the birds of prey may colonize the territory of the Donetsk Ridge due to this trend in nesting habits.

\section{References}

Banik, M. V., \& Korshunov, A. V. (2014). Nazemnye pozvonochnye ukrainskoy chasti basseyna Severskogo Dontsa: Sovremennoe sostoyanie, tendentsii izmeneniya chislennosti i problemy ohranyi [Terrestrial vertebrates of Ukrainian part of Siversky Donets river basin: Current state, trends of changes in numbers, and protection problems]. Visnik Harkivskogo Natsionalnogo Universitetu Imeni V. N. Karazina, Seriya Biologiya, 20(1100), 91-103 (in Russian).

Belik, V. P. (2000). Ptitsyi stepnogo Pridonya. Formirovanie fauny, ee antropogennaya transformatsiya i voprosyi ohranyi [Birds of the Steppe Pridonye. Fauna formation, its anthropogenic transformation and protection issues]. Izdatelstvo Rostovskogo Gosudarstvennogo Pedagogicheskogo Universiteta, Rostov-na-Donu (in Russian).

Brygadyrenko, V. V. (2015). Influence of tree crown density and density of the herbaceous layer on the structure of litter macrofauna of deciduous forests of Ukraine's steppe zone. Visnyk of Dnipropetrovsk University, Biology, Ecology, 23(2), 134-148.

Brygadyrenko, V. V. (2016). Evaluation of ecological niches of abundant species of Poecilus and Pterostichus (Coleoptera: Carabidae) in forests of the steppe zone of Ukraine. Entomologica Fennica, 27(2), 81-100.

Burgas, B., Byholm, P., \& Parkkima, T. (2014). Raptors as surrogates of biodiversity along a landscape gradient. Journal of Applied Ecology, 51(3), 786-794.

Butet, A., Michel, N., Rantier, Y., Comor, V. N. R., Hubert-Moy, L., Nabucet, J., \& Delettre, Y. R. (2010). Responses of common buzzard (Buteo buteo) and Eurasian kestrel (Falco tinnunculus) to land use changes in agricultural land- 
scapes of Western France. Agriculture, Ecosystems and Environment, $138(3-4), 152-159$

Czernay, A. (1851). Nachtrag zur meinen Beobachtungen bezug auf die Fauna des Charkowschen und anliegenden der Stadt. Bulletin de la Société Impériale des Naturalistes de Moscou, 24(1), 269-282 (in German).

Galushin, V. M. (1971). Chislennost i territorialnoe raspredelenie hischnyih ptits Evropeyskogo tsentra SSSR [Number and territorial distribution of birds of prey of the European Center of the USSR]. Trudyi Okskogo Zapovednika, 8, 5-132 (in Russian).

Gavrilyuk, M. N. (2009). Metodichni rekomendatsiyi do programi monitoringu hizhih ptahiv Ukrayini [Methodological recommendations for the birds of prey monitoring program of Ukraine]. Cherkasy (in Ukrainian).

Ivlev, V. S. (1955). Eksperimentalnaya ekologiya pitaniya ryib [Experimental ecology of fish nutrition]. Pischepromizdat, Moscow (in Russian)

Jacobs, J. (1974). Quantitative measurement of food selection: A modification of the forage ratio and Ivlev's electivity index. Oecologia, 14(4), 413-417.

Karyakin, I. V. (2000). Metodicheskie rekomendatsii po uchyotu pernatyh hischnikov i obrabotke uchyotnyih dannyih [Guidelines for counting raptors and processing credentials]. Manuskript, Novosibirsk (in Russian).

Kohanov, V. D. (2000). K itogam poluvekovogo izucheniya ornitofauny okrestnostey Krasnogorovki bliz Donetska [On the results of a half-century study of the avifauna of the surroundings of Krasnogorovka near Donetsk]. Ptitsyi Basseyna Severskogo Dontsa. Materialy 6 i 7 Konferentsii "Izuchenie i Ohrana Ptits Basseyna Severskogo Dontsa”, Donetsk, 6-7, 40-48 (in Russian).

Kruger, O. (2002). Analysis of nest occupancy and nest reproduction in two sympatric raptors: Common buzzard Buteo buteo and goshawk Accipiter gentilis Ecography, 25, 523-532.

Kul'bachko, Y. L., Didur, O. O., Loza, I. M., Pakhomov, O. E., \& Bezrodnova, O. V. (2015). Environmental aspects of the effect of earthworm (Lumbricidae, Oligochaeta) tropho-metabolic activity on the $\mathrm{pH}$ buffering capacity of remediated soil (steppe zone, Ukraine). Biology Bulletin, 42, 899-904.

Milobog, Y. V. (2012). Sokolopodibni (Falconiformes) stepovoyi zony Ukrayiny: Vydoviy sklad, terytoryalniy rozpodil, dynamika chyselnosti ta ohorona [Falconiformes of the steppe zone of Ukraine: Species composition, territorial distribution, number dynamics and conservation]. Kyiv (in Ukrainian).
Morris, P. (1995). Methods of environmental assessment. University College of London Press.

Newton, I. (1979). Population Ecology of Raptors. T \& AD Poyser, Berkhamsted.

Palomino, D. \& Carrascal, L. M. (2007). Habitat associations of a raptor community in a mosaic landscape of Central Spain under urban development. Landscape and Urban Planning, 83, 268-274.

Panchenko, S. G. (2016). Ptitsyi Luganskoy oblasti [Birds of Lugansk region] Kollegium, Kharkov (in Russian).

Romanov, M. S. (2005). Hischnyie ptitsyi i chernyiy aist v rastitelnom pokrove Nerusso-Desnyanskogo polesya [Birds of prey and black stork in the vegetation of Nerusso-Desniansky woodland]. Izuchenie i ohrana biologicheskogo raznoobraziya Bryanskoy oblasti. Trubchevsk. Pp. 190-210 (in Russian)

Romanov, M. S., \& Evstigneev, O. I. (2016). Mestoobitaniya hischnyih ptits i chernogo aista $\mathrm{v}$ svyazi s prostranstvennoy strukturoy lesnogo pokrova [Habitats of diurnal raptors and the black stork in relation to the spatial structure of forest cover]. Russian Journal of Ecosystem Ecology, 1(3), 1-20 (in Russian).

Rudinskiy, O. M., \& Gorlenko, L. S. (1937). Do fauni hizhih ptahiv serednoyi techiyi Pivnichnogo Dintsya [On the fauna of birds of prey in the middle reaches of the North Donets]. Zbirnik Prats Zoologichnogo Muzeyu AN URSR, 20, 141-155 (in Ukrainian).

Shischenko, P. G. (1988). Prikladnaya fizicheskaya geografiya [Applied physical geography]. Vyischa Shkola, Kyiv (in Russian).

Somov, N. N. (1897). Ornitologicheskaya fauna Harkovskoy gubernii [Ornithological fauna of Kharkiv province]. Kharkov (in Russian).

Sunde, P., Odderskaer, P., \& Storgaard, K. (2009). Flight distances of incubating common buzzards Buteo buteo are independent of human disturbance. Ardea, 97(3), 369-362.

Vetrov, V. V. (1993) Sostav i raspredelenie hischnyih ptits basseyna Severskogo Dontsa [Composition and distribution of birds of prey in the Seversky Donets basin]. Ptitsyi Basseyna Severskogo Dontsa. Konferentsiya "Izuchenie i ohrana ptits basseyna Severskogo Dontsa”. DonGU, Donetsk. Pp. 33-38 (in Russian).

von Nordmann, A. (1840). Observations sur la fauna pontique in A. Voyage dans la Russie méridionale et la Crimee. Paris, 3, 35-63 (in Finnish). 